\title{
Housing and Social Development: Linking Social and Economic Aspects of Development through Housing Delivery
}

\author{
Mziwandile Sobantu
}

The aim of this article is to highlight the nexus between housing delivery and social development. Social development as a theoretical lens aims at harnessing economic dividends toward social investments that will improve people's lives. South Africa's housing and social policies are well developed. However, housing delivery planning and practice requires thoughtful appreciation of the role of housing delivery in ameliorating poverty, inequality, and unemployment. Currently, the country faces interrelated challenges of a sluggish economy, unemployment, and low social collegiality evidenced by crime, gender-based violence, and abuse against children. Drawing from literature, this reflective paper underscores the centrality of adequate housing delivery in generating employment, stimulating home-grown economic enterprises, boosting health, and growing the economy. Housing-based partnerships are critical in driving social and economic growth. The author recommends that housing, as a social policy, should be integrated with economic planning.

Keywords: economy, housing delivery, social development, social policy, South Africa

\section{Introduction}

The 2030 Agenda on Sustainable Development emphasizes that development efforts need to be undertaken in a manner that "leave[s] no one behind ... attacking the root causes that generate and reproduce economic, social, political, environmental problems and inequities" (United Nations Research Institute for Social Development [UNRISD], 2018, p. 32). This call is in view of the structural impediments that exist, especially in developing countries, which perpetuate inequality

Mziwandile Sobantu, PhD, Lecturer, University of Johannesburg, Faculty of Humanities, Department of Social Work, Johannesburg, South Africa, msobantu@uj.ac.za; sobantu.mzwandile@gmail.com 
and poverty. Social development therefore attempts to confront these barriers in order to promote social justice through redistribution (Noyoo, 2015; Patel, 2015). The potential of housing delivery to connect families and communities with essential social and economic services has long been recognized (Arku, 2006). It is the author's view that housing in South Africa has not been fully utilized as a more deliberate strategy to galvanize people's social and economic rights. For a country that is emerging from years of colonial and apartheid misrule (Patel, 2015), South Africa's housing policy urgently needs to be coupled with economic planning so as to promote social justice, nation building, and economic growth (Noyoo \& Sobantu, 2019). The impact of novel corona virus, known as Covid-19 in the country, reverberates the calls for government to prioritize providing adequate housing especially to the low-income households.

Informed by a social development lens, this article is a literature appraisal of the linkages between housing and social development. The major thrust of social development is to ensure that economic growth results in perceptible improvements in people's lives. Midgley (1995) defined social development as:

$[A]$ process of planned social change designed to promote the welfare of the population as a whole in conjunction with a dynamic process of economic development. (p. 250)

Using examples from South Africa, the article highlights the value of housing delivery in connecting families with essential services and opportunities. Since 1994, the South African government has enacted progressive developmental policies, which are however being undermined by poor implementation (Ncube, 2019; Noyoo, 2015). With the country's poor economic outlook and weak social collegiality, seen through the incessant scourge of gender-based violence (GBV) and domestic violence (DV), it is imperative to find innovative ways of fostering social cohesion while addressing inequality and poverty. The author concurs with Mkandawire (2004, p. 2) who stressed that "[housing, as part of] social policy needs to be adopted in tandem with economic growth as instruments for the elimination of poverty." Gray (2006) and Ncube (2019) argued that government and practitioners in various sectors in South Africa are grappling with implementing projects that will accelerate growth and create social incentives for the poor. Furthermore, Noyoo and Sobantu (2019) pointed out that the merit of housing in poverty alleviation and stimulating worth is loosely presented in economic policy.

The article first discusses the global evolution of social development as a developmental approach, followed by a focus on the South African perspective of a developmental paradigm. Thereafter, it looks at the centrality of housing delivery in generating employment, supporting home-based microenterprises (HBMEs), and promoting health-all of which contribute to social and economic progress. The implications for housing and social policy are discussed before the conclusion section. 


\section{The Global Evolution of Social Development}

This section gives a brief historical evolution of social development. While doing so, the author clarifies the logic of merging the social and the economic streams of development, and the centrality of housing in conjoining the two. As an approach to social welfare, social development dates back to the end of the two World Wars (Noyoo, 2015). The Cold War and the decolonization of African and Asian states from European rule posed numerous social and economic challenges on Europe and the United States, calling for innovative ways to meet the basic needs and to rebuild the continent (Noyoo, 2015). As part of the efforts to address the foregoing developmental challenges, the then US Secretary of State, George Marshall, funded socioeconomic programs to rehabilitate Europe (Noyoo, 2015). At that time, serious engagements were also initiated globally, to ensure that industrialization and economic growth had a trickle-down effect in improving people's living conditions (Noyoo, 2015). Growth related to human development is "development with a human face," according to Mehrotra and Jolly (2000). Since then, the notion of "trickling down" the benefits of growth to improving access to housing, health care, education, and participation became the thrust of development. That is merging the economic and social facets of development, which is the essence of social development (Midgley, 1995).

It should be noted that such development was a break from the modernization theorists' understanding of progress, who viewed development as synonymous with production and economic growth (Noyoo, 2015). To the proponents of modernization, prioritizing housing and health was costly to the economy, viewing them as automatic outcomes of economic growth. Modernization theorists' understanding of housing delivery was that it was not "a meaningful development strategy... [but] a resource-absorber ... consumer good ... and a social overhead" (Arku, 2006, p. 379). Also, dependency theorists pointed out that tackling structural impediments, such as poverty, unemployment, and inequality, were imperative in catalyzing growth and redistribution (Sen, 1999).

The founding of the United Nations (UN) in the 1940s hastened global consolidation of social development. The UN urged signatory countries to come up with "policy measures [that] protect the welfare of the vulnerable in society" (Noyoo, 2010, p. 23) through the "economic policies that are socially sensitive" (Mkandawire, 2004, p. 1). In the same vein, the World Bank implored governments to come up with measures that prioritize people in development thinking and practice. Part of these measures involved tackling structural challenges, such as inequality and poverty, by providing social investments that include housing. The 1990 United Nations Development Programme (UNDP) report also emphasized people-centered development to fight poverty, and the same was the focus of the 2000 Millennium Development Goals (MDGs) as well. With respect to housing delivery, the 1948 Universal Declaration of Human Rights (UNDHR) described housing as more than just "brick and mortar." The UNDHR underscored that housing is a right that needs to link the occupants to economic 
opportunities and water, sanitation, domestic electricity, and other services and amenities.

Today, social development is accepted worldwide as a social welfare approach through which economic progress can be harnessed toward improving people's well-being. Varma (1990) in Gray, Mazibuko, and O’Brien (1996, p. 35) described social development as a kind of development:

$[W]$ ith a renewed interest in human beings ... as a comprehensive concept incorporating political, economic and cultural changes as part of deliberate actions to transform society.

However, as observed by Gray (2006) and Ncube (2019), the South African government faces a challenge of implementing social development as an approach to social welfare.

\section{Social Development in the Context of South Africa}

Social development in post-apartheid South Africa is informed by the developmental challenges that confronted the country in 1994. As a legacy of apartheid, poverty, inequality, and unemployment posed a threat to reconciliation, nation building, and economic growth (Gray et al., 1996). Pre-1994, the majority of blacks were excluded from housing access and other essential services (Noyoo, 2015; Sobantu, 2020). In 1994, South Africa had a shortfall of 1.5 million houses, while more than 7 million people had resorted to informal settlements, most of which were dislocated from economic opportunities, in far-flung urban peripheries (Noyoo \& Sobantu, 2019). The country's perpetual housing challenge has always dominated the discourses of social development, human rights, human dignity, growth, and social justice, among others.

In 1994, the African National Congress (ANC)-led government initiated policies to address the developmental gaps that it had inherited. It consulted widely with its alliance partners, and subsequently promulgated the 1994 Reconstruction and Development Program (RDP), with its pro-poor ethos and inclusiveness in addressing the existing welfare challenges (Gray, 2006; Gray et al., 1996). As articulated in the RDP, providing social welfare services was to be informed by the principles of empowerment, human development, human worth and dignity, gender equality, and democracy and participation (Republic of South Africa [RSA], 1994a). The strategic position of housing delivery in contributing to all the foregoing principles needs to be noted. The White Paper for Housing was also enacted in 1994 to facilitate the delivery of quality housing, in socially and economically viable settlements (RSA, 1994b). Further, consultations with other key stakeholders by the government led to the promulgation of the 1997 White Paper for Social Welfare (Ministry of Welfare and Population Development, 1997), hereinafter referred to as the White Paper. The White Paper provided a blueprint for social development (Noyoo, 2015) and set the tone for sustainable growth to 
progressively eradicate poverty and inequality in the country (Gray et al., 1996; Patel, 2015). South Africa has progressed well in terms of aligning its social development ambitions with international law. Consonant with the UNDHR, the 1996 South African Constitution declares housing as a right, and as one of the social welfare services that are "critical to building a united South Africa, based on democratic values and social justice” (Patel, 2005, p. 98).

Since 1994, South African scholars such as Lombard (2007), Noyoo (2015), and Patel (2015) have been at the forefront of providing useful insights for conceptualizing social development and its application in practice. Lombard (2007) asserted that social development is:

...[D]istinguished as (1) an ultimate (end) goal of development activities; and (2) as an appropriate approach to social welfare and thus an intervention strategy that incorporates social and economic processes to achieve social development as its ultimate goal. (p. 299)

Thus, development programs, especially housing delivery, ought to be meticulous, informed by deliberate thoughts about food, adequate shelter, health, education, and the incomes of the people (United Nations, 1948). In order to create an inclusive social welfare system, Patel (2005, p. 98) proposed five key pillars, which stress that the delivery of welfare services should be conducted in an inclusive manner, which yields both economic and social benefits. These pillars are: (1) welfare pluralism through partnerships; (2) rights-based approach; (3) establishing a deliberate relationship between social and economic development; (4) ensuring democracy and participation in development; and (5) bridging the macro and micro divide in development. Of particular importance to this article is the social and economic pillars and how they should to be conceptualized and applied in housing delivery - using South Africa as an example. Drawing from Midgley (1995), Noyoo (2015) envisaged the social development approach in post-1994 South Africa as a strategy to enhance the redistribution of income, and fast-track investment in education and other social services, such as housing, and thereby tackle distorted development.

While social development was "adopted wholeheartedly" (Gray, 2006, p. 54) and even influenced the aspirations of South Africa's National Development Plan (NDP) in 2011, its application and effectiveness in the country has been questioned. Secondly, in spite of an increase in literature that highlights housing delivery progress and related challenges in South Africa, there have been very few practical propositions on how exactly housing could yield social development dividends for the poor. In other words, the practical housing-social development nexus has not been explored both in literature and application. The 2.1 million housing shortfall, increase in informal settlements since 1994, fragmented housing delivery, high unemployment rates, and growing poverty (Noyoo \& Sobantu, 2019) are some of the indicators that warrant a deep thought toward purposeful social-development-informed housing delivery in South Africa. 


\section{Economic and Social Dividends through Housing Delivery}

The discussion on the significance of housing delivery to stimulate growth and create social gains is not new. Popular beliefs concerning housing in the $1950 \mathrm{~s}$ were of the perception that housing delivery needed to wait until the economy had grown to finance the costs of housing infrastructure. From such perspectives, housing delivery was perceived as a by-product of economic growth (Solow, 1955, p. 52 in Arku, 2006, p. 379). This understanding is appreciated within Kaseke (2015):

[T] he modernisation approach to development whose overriding concern was to create economic growth with the central assumption that the benefits of this economic growth would trickle down to everyone in society. (p. 187).

Because of the foregoing strong views, resource and budget allocation toward housing delivery remained negligible, as shown by Arku (2006). Also, the proponents of housing prioritization questioned, "why must widespread improvement in the home environment wait until the basic economy can provide higher incomes" (Bauer, 1955, p. 39 in Arku, 2006, p. 383). A social development stance insists that developing the economy requires labor that is satisfied with its health and living environment. Although marred by criticism, the South African government has, since the dawn of democracy, demonstrated its dedication to provide mass housing for its poor citizens. Drawing some examples from South Africa, the following section discusses three key strategies of strengthening the housing delivery-social development nexus.

\section{Housing, Employment Creation, and Economy}

Housing construction serves as a catalyst for the establishment of the upstream and downstream industries. For example, the housing construction process requires "building materials production and marketing and distribution of construction materials and equipment" (Arku, 2006, p. 387), which thrives on an efficient communication system, transport network, and infrastructure. These backward and forward industries boost the property market, which generates revenue, creates jobs, and contributes to the economy. The off-construction site services that emerge in response to housing construction are also to be considered. Some of these services and industries can be identified to benefit unemployed graduates and provide much-needed opportunities for internship programs to acquire skills. Linked with institutions of higher learning (IHL) and technical colleges, students and graduates in land surveying, drafting, welding, and carpentry, to mention a few, can be channeled to these institutions to gain practice and experience employment (Arku, 2006; Carter \& Polevychok, 2004).

Strong partnerships between these different actors are essential to ensure the maximization of employment opportunities within the sector, especially for 
South Africa, which is struggling with a high rate of unemployment among the youth. Partnerships are pivotal in implementing social development. Both the MDGs and the Sustainable Development Goals (SDGs) underscore the centrality of partnerships in sharing knowledge, opportunities, skills, and innovative ideas toward economic growth. For the youth to benefit from the employment and internship opportunities that exist in the construction-related sectors, there needs to be "partnerships with provinces, municipalities, academia, civil society [and the] youth" (Kreda, 2017, p. 53). The fragmented nature of housing planning within government and with other stakeholders in the country frustrates the strategic deployment of unutilized, skilled, and semi-skilled labor to benefit from the construction industry and contribute to the economy (Noyoo \& Sobantu, 2019). It should be noted that South Africa has a high youth unemployment rate, estimated as 55.2 percent (Statistics South Africa [Stats SA], 2019). Furthermore, Stats SA (2020) reported that 40.1 percent of the 20.4 million young people (aged 15-24 years) were not in employment, education or training (NEET). Lessons from Singapore, Japan, and Columbia indicate that stringing together youth-focused housing construction partnerships can target youth unemployment effectively (Arku, 2006).

South Africa prides itself on having a healthy housing property market, from which economic transactions could benefit the poor more significantly (Centre for Affordable Housing Finance in Africa [CAHF], 2018). From 1994 to 2014, the government had spent R125 billion toward the capital subsidy housing program to build 2.8 million houses (CAHF, 2018; RSA, 2014). Rust (2012) indicated that by September 2010, 1.44 million RDP houses had been registered on the National Deeds Registry, and exactly a year later, 6 percent of these units had been sold to new buyers, some of whom had already applied for housing improvement finance. According to Rust (2012), R12 billion was realized from the sale of only 6 percent of the RDP houses referred to in the foregoing sentence. Obviously, major banks and some microfinance institutions (MFIs) benefited from financing these transactions, and some skilled and semi-skilled individuals were employed to improve the units.

The below excerpt from Rust (2012, p. 4) elaborated on the extent of housing loan transactions in Africa, which also reflected the centrality of housing in people's social lives and in also growing the economy:

According to MixMarket, the gross loan portfolio across 664 micro lenders in Africa in 2011 was $\$ 6.6$ billion ... it has been suggested that upwards of $30 \%$ of a micro lending book is typically used for housing purposes. This could mean a \$2 billion investment across Africa in housing, with loans that the MixMarket suggests an average balance of $\$ 455.80$. Approaching the notion of incremental housing investment from the demand side, Kihato (2009) suggests an estimated urban demand for housing microfinance in Africa to the value of $\$ 8$ billion.

While MFIs generate huge financial capital from housing loans, very little is known about the qualitative improvements in people's lives resulting from these transactions. In South Africa, such huge transactions could deliberately 
be deployed in less developed provinces, such as Eastern Cape and Limpopo, to address geographical infrastructure inequality and tackle emigration and poverty in these communities.

Housing, Micro and Small Enterprises, and the Economy

Turner (1972) stressed the use-value of a house, no matter how poorly constructed and cheap the structure may be. In South Africa, there is a strong intersection between home ownership and small-scale enterprises, where a house is utilized as a base for various income-generating activities. Arku (2006, p. 382) referred to these activities as home-based enterprises (HBEs). In spite of much criticism leveled against RDP housing (Aigbavboa \& Thwala, 2013, p. 17; Noyoo \& Sobantu, 2019), there is also evidence of the existence of HBEs that are known to complement family incomes in these settlements (Rust, 2012; Rust, Zack, \& Napier, 2009). Having additional units in the backyard is very common in South Africa. Usually, the units are then rented out to generate income (Rust, 2012). Backyard accommodation in well-located areas is often preferred to the far-flung informal settlements and dislocated RDP houses, because it is proximal to economic opportunities and also connected to basic services and amenities (Rust et al., 2009). As a result, both the landlords and tenants benefit financially and may channel savings toward nutrition and children's education.

The economic potential of rental housing, including the backyard structures, is reflected by Shisaka (2006, p. 8) in Rust (2012, p. 8) who revealed that the sector accommodated "over 1.8 million low-income people, with an average income of R1,800, collectively earning an estimated R420 million." Other than rentals, grocery shops and crèches are very common forms of businesses in residential properties. These are centers of both economic and social activities, fostering social inclusion, social capital, and safety and security in the community. While providing employment, these crèches also contribute immensely to the cognitive and physical development of children, which Lombard (2011, p. 535) referred to as social investments that guarantee the "future functioning" of families and the economy. With the current 'lockdown' and subsequent home-schooling due to Covid-19 in the country, families and government are realizing the centrality of adequate housing to children's education and development.

In the unstable world economic climate, where retrenchments from mines are common, as in the case of South Africa (Ndweni, 2016), promoting HBEs may provide a solution for the unemployed, semi-skilled labor. The HBEs, such as carpentry, spray-painting, cooking, and even sewing and laundry, are some of the enterprises that financially support many families in South Africa (Rust, 2012), Ghana (Arku, 2006), Kenya (Muraya, 2006), Lusaka in Zambia (Arku, 2006, p. 389), Egypt (Tipple, 2005), and Venezuela (Chen, Sebstad, \& O'Connel, 1999). With the changing nature of work, Arku (2006) also highlighted that a number of individuals work from home and thus turn their residential properties into productive centers and points of economic activities. Globally, Covid-19 has forced workers, students, and learners to work from their homes to prevent further 
infections and facilitate social distancing. It is hence imperative that the South African government rethinks the role of housing in the changing global, social, and economic climate, and support these HBEs.

Housing Quality, Human Dignity, Health, and the Economy

The link between housing, health, and productivity is well established (Arku, 2006). Any nation that prioritizes economic growth, while disregarding health, improvements to housing quality, and human dignity as subsidiaries, is "suicidal" to its people and its economy. Li, Chen, and Powers (2012) pointed out that a country that neglects its people's need for well-being is like:

$[A]$ person with one long leg, one short one- $\mathrm{a}$ [Chinese] metaphor for how strong economic growth needs social development and bettering of people's livelihoods. (p. 639)

Thus, not just a house, but quality housing, which is connected with sanitation and is located in close proximity to health-care facilities influences productivity and health in a positive way. The severe acute respiratory syndrome (SARS) in China during 2002-2003 made the government realize that "a healthy workforce not only reduces overall healthcare costs, but also helps boost overall economic productivity" (Li et al., 2012, p. 640). Employees that occupy well-located, quality, and affordable housing are more likely to have a positive sense of worth, which enhances their dignity, and because of this positive self-image, they are less likely to be absent from work due to housing-related stress (Arku, 2006). There is a strong correlation between overcrowding and stress and diseases, such as cholera and tuberculosis (Rankine, 2005). Individual and government responses to these maladies are costly, employing resources that could be channeled toward development efforts.

In spite of much improvement on the size and quality of initial RDP houses, South Africa's subsidy housing is synonymous with poor workmanship. Pre1994, the majority of blacks occupied dehumanizing living conditions, which were designed to "kill a man's pride and produce dehumanised people" (Matshoba, 1980, p. 177). As a consequence, their health, self-esteem, and human dignity were affected, and they were forced to be economically productive through hard labor and slavery (Noyoo \& Sobantu, 2019). Even to date, more than 7 million people reside in dehumanizing informal settlements, some of which are not integrated with basic services such as water and sanitation (Noyoo \& Sobantu, 2019). Most protests in the country revolve around such housing-related challenges (Sobantu, Zulu, \& Maphosa, 2019), and these incidents have serious economic ramifications (De Villiers, 2017). The Eastern Cape alone recorded 2,045 of such protests in 2015 (Mukhuthu, 2015). The impact on the economy is huge, particularly if these incidents are violent, damage property, and in some instances are accompanied by the loss of work hours due to labor strikes. 
Poor-quality housing poses adverse economic implications for both the occupiers and the government. As already indicated, the government built 2.8 million houses between 1994 and 2014, which cost R125 billion (CAHF, 2018; RSA, 2014). From the 2017 General Household Survey, 10 percent of all capital subsidy houses was found to be of poor quality (Stats SA, 2017). Khan and Thring (2003, p. 18) indicated that some of these houses were "relatively expensive to maintain" because of poor workmanship. As a consequence, in 2009, the government indicated that it required R1.3 billion to repair the serious defects in these units (RSA, 2009). The affected beneficiaries incurred a double loss of dignity, due to poor housing and the financial costs they incurred in conducting repairs, as some owners are reported to have fixed the damages themselves (Manomano \& Tanga, 2018). It is in the light of the foregoing reflections that Gray (2006, p. S54) argued that the ANC government has reneged on its social development approach to social welfare.

\section{Conclusion}

This article has endeavored to establish the resonance between housing and social development, specifically in the area of social and economic development. In line with Arku (2006), Carter and Polevychok (2004), and Jenkins and Smith (2001), the article contends that housing delivery should be a thoughtful process, benefiting the poor to live in secure settlements that are connected to amenities and economic opportunities. In fighting GBV and DV, addressing unemployment and inequality, promoting health of citizens, stimulating economic growth, and advocating human development, South African government and stakeholders should consider prioritizing adequate housing delivery. It is time that the government became aware that "housing is good social policy" (Carter \& Polevychok, 2004, p. iv). Added to its housing planning espoused in housing policies, governments, especially in South Africa, should deliberately treat housing as a productive sector of development than merely as a costly exercise. The author recommends that strong housing partnerships in all tiers of government should ensure that housing needs are identified, and affordable quality housing is provided in a more transparent manner. Also, the private sector needs to take responsibility for contributing to housing policy and also play an active role in providing adequate housing for their employees. Because of the centrality of housing in social development, it is imperative that discussions concerning budget for housing should take "place at the [same] table with education and healthcare when spending priorities are discussed" (Carter \& Polevychok, 2004, p. vi).

\section{References}

Aigbavboa, C. O., \& Thwala, W. D. (2013). Residents' perception of subsidised low-income housing in South Africa: A case study of Kliptown, Johannesburg. 
Journal of Human Ecology, 42(1), 17-23. doi:10.1080/09709274.2013.119 06577

Arku, G. (2006). The housing and economic development debate revisited: Economic significance of housing in developing countries. Journal of Housing and the Built Environment, 21(4), 377-395. doi:10.1007/s10901-0069056-3

Carter, T., \& Polevychok, C. (2004). Housing is good social policy. Ottawa: Canadian Policy Research Networks.

Centre for Affordable Housing Finance in Africa. (2018). Housing. Retrieved from http://housingfinanceafrica.org/countries/south-africa

Chen, M., Sebstad, J., \& O'Connell, L. (1999). Counting the invisible workforce: The case of homebased workers. World Development, 27(3), 603-610. doi:10. 1016/S0305-750X(98)00154-5

De Villiers, J. (2017). South African tourism: Negative effects of marches and protests. Retrieved from https:/www.cnbcafrica.com/news/2017/04/12/negativeeffects-marches/

Gray, M. (2006). The progress of social development in Southern Africa. International Journal of Social Welfare, 15, S53-S64. doi:10.1111/j.1468-2397.2006.00445.x

Gray, M., Mazibuko, F., \& O’ Brien, F. (1996). Social work education for social development. Journal of Social Development in Africa, 11(1), 33-42.

Hai, W., Zhao, Z., Wang, J., \& Hou, Z. G. (2004). The short-term impact of SARS on the Chinese economy. Asian Economic Papers, 3(1), 57-61. doi:10.1162/ 1535351041747905

Jenkins, P., \& Smith, H. (2001). An institutional approach to analysis of the state capacity in housing systems in the developing world: Case studies in South Africa and Costa Rica. Housing Studies, 16(4), 485-507. doi:10.1080/ 02673030120066563

Kaseke, E. (2015). Social development and education: Reflections from Southern African perspective. In L. Calvelo, R. Lutz, \& R. Ross (Eds.), Development and social work: Social work of the south (pp. 187-199). Oldenburg: Paulo Freire Verlag.

Kihato, M (2009, September). Scoping the demand for housing microfinance in Africa: Status, opportunities and challenges. Paper prepared for FinMark Trust's Centre for Affordable Housing Finance in Africa on 01 September 2009, Johannesburg, South Africa. Retrieved from http://housingfinanceafrica. org/app/uploads/HMF_Africa.pdf

Khan, F., \& Thring, P. (Eds.). (2003). Housing policy and practice in post-apartheid South Africa. Cape Town: Heinemann Publishers.

Kreda, J. (2017). Housing perspectives on Habitat III: Canada. Cityscape, 2, 53-56.

Li, L., Chen, Q., \& Powers, D. (2012). Chinese health care reform: A shift toward social development. Modern China, 38(6), 630-645. doi:10.1177/ 0097700412457913

Lombard, A. (2007). The impact of social welfare services on social development in South Africa: An NGO perspective. Social Work/Maatskaplike Werk, 43(4), 295-316. doi:10.15270/43-4-260 
Lombard, A. (2011). Book review. Social work and social development: Theories and skills for developmental social work. Social Work/Maatskaaplike Werk, 47(4), 534-538. doi:10.15270/47-4-121

Manomano, T., \& Tanga, P. (2018). Housing needs: The quality and quantity of housing provided by the government for the poor in the Eastern Cape Province in South Africa. Social Work/Maatskaaplike Werk, 54(1), 19-36. doi:10.15270/54-1-612

Matshoba, M. (1980). To kill a man's pride. In M. Mutloatse (Ed.), Forced landing (pp. 103-127). Johannesburg: Ravan Press.

Mehrotra, S., \& Jolly, R. (2000). Development with a human race: Experiences in social achievement and economic growth. Oxford: Oxford University Press.

Midgley, J. (1995). Social development: The developmental perspective in social welfare. London: Sage Publications.

Ministry of Welfare and Population Development. (1997). White paper for social welfare. Government Gazette. 386(18166), (8 August). Pretoria: Government Printer.

Mkandawire, T. (2004). Introduction. In T. Mkandawire (Ed.), Social policy in a development context (pp. 1-33). Hampshire: Palgrave Macmillan.

Mukhuthu, Z. (2015, October 2). Eastern Cape police pleased with annual crime stats. Daily Dispatch, 1. Retrieved from http://www.dispatchlive.co.za/ news/2015/10/02/eastern-cape-police-pleased-with-annual-crime-stats/

Muraya, P. W. (2006). Urban planning and small-scale enterprises in Nairobi, Kenya. Habitat International, 30(1), 127-143. doi:10.1016/j.habitatint. 2004.08.002

Ncube, M. (2019). Conceptualising social development supervision in social work. The Indian Journal of Social Work, 79(1), 31-46. doi:10.32444/IJSW. 2018.80.1.31-46

Ndweni, B. (2016). The reality of retrenchment. Finweek. Retrieved from https:// www.fin24.com/Finweek/Personal-finance/the-reality-of-retrenchment20160517

Noyoo, N. (2010). Social policy and human development in Zambia. London: Adonis \& Abbey Publishers Ltd.

Noyoo, N. (2015). Social development in Southern Africa. In L. Calvelo, R. Lutz, \& R. Ross (Eds.), Development and social work: Social work of the South (pp. 167185). Oldenburg: Paulo Freire Verlag.

Noyoo, N., \& Sobantu, M. (2019). Deconstructing and decolonising spatiality: Voluntary and affordable housing for a transforming Johannesburg. In M. T. Myambo (Ed.), Reversing urban spatiality (pp. 35-42). London: Routledge.

Patel, L. (2005). Social welfare E social development in South Africa. Cape Town: Oxford University Press.

Patel, L. (2015). Social welfare E social development in South Africa (2nd ed.). Cape Town: Oxford University Press.

Rankine, J. (2005). Housing and health in Auckland: A summary of selected research. Auckland: Auckland Regional Public Health Service. 
Republic of South Africa. (1994b). White paper for housing. Cape Town: Government Gazette.

Republic of South Africa. (1994a). White paper for reconstruction and development. Cape Town: Government Gazette.

Republic of South Africa. (2009). Department of housing and human settlements, housing code. Pretoria: Government Printer.

Republic of South Africa. (2014). Twenty-year review South Africa, 1994-2014. Background paper on human settlements. Pretoria: Department of Human Settlements.

Rust, K. (2012). Housing matters: The importance of housing finance in financial sector development in Africa. Johannesburg: Centre for Affordable Housing Finance in Africa.

Rust, K., Zack, T., \& Napier, M. (2009). How a focus on asset performance might help "Breaking New Ground" contribute towards poverty reduction and overcome the two-economies divide. Town and Regional Planning, 54, 51-61.

Sen, A. (1999). Development as freedom. Oxford: Oxford University Press.

Sobantu, M. (2020). Revisiting gender and housing: Housing as seen through the eyes of women in social rental housing in Gauteng, South Africa. Social Work/Maatskaaplike Werk, 56(1), 66-77. doi:org/10.15270/52-2-790

Sobantu, M., Zulu, N., \& Maphosa, N. (2019). Housing as a basic human right: A reflection on South Africa. Southern African Journal of Social Work and Social Development, 31(1), 1-18. doi:10.25159/2415-5829/4177

Statistics South Africa. (2017). Statistical release, P0318: General household survey. Retrieved from http://www.statssa.gov.za/publications/P0318/P03182017. pdf. Author

Statistics South Africa. (2019). Statistical release, P0211: Quarterly labour force survey, Quarter 1, 2019. Retrieved from http://www.statssa.gov.za/publications/ P0211/P02111stQuarter2019.pdf

Statistics South Africa. (2020). Quarterly labour force Survey (QLFS) Q4:2019. Retrieved from http://www.statssa.gov.za/publications/P0211/ P02114thQuarter2019.pdf

Tipple, G. (2005). The place of home-based enterprises in the informal sector: Evidence from Cochabamba, New Delhi, Surabaya and Pretoria. Urban Studies, 42(4), 611-632.

Turner, F. C. (1972). The re-education of a professional and housing as a verb. In J. Turner \& R. Fichter (Eds.), Freedom to build (pp. 148-150). New York, NY: Macmillan.

United Nations. (1948). Universal declaration of human rights. New York, NY: United Nations.

United Nations Research Institute for Social Development [UNRISD]. (2018). 2030 Agenda for sustainable development. New York, NY: United Nations. 